\title{
Semarang City Government Policy on Medical Waste Management of Dental Clinics and Independent Practicing Dentists
}

\author{
(Kebijakan Pemerintah Kota Semarang dalam Pengelolaan Limbah Medis Klinik Gigi dan \\ Dokter Gigi Praktik Mandiri)
}

\author{
Pascalin Fiestarika Indraswari; C. Tjahjono Kuntjoro; Yovita Indrayati \\ email: pascalinfiestarika@gmail.com
}

Master of Health Law, Soegijapranata Catholic University Semarang

\begin{abstract}
The number of dental clinics and dentist independent practices in Semarang city has increased every year. This also increases the potential production of the dental health care waste. They could potentially harm the health care personnel, patients, and also the environment because of their harzardous nature. Therefore, Semarang City Government's role in regulating and making policies is crucial. This study will not just analyze Semarang City Government policies in managing health care waste in dental clinics and independent dentist practices, but also identify the factors that support or inhibit the implementations.

This research was held in Semarang City using sociological juridical approach and presented descriptively and analytically. Primary data was collected through observation and interviews. Secondary legal data is obtained by collecting legal and non-legal theories. In addition, the authors also assess all regulations and policies from central to local governments that are relevant to this topic. The research sample was taken from clinics that run dental services and independent dentist pravtices in Semarang city. The sample was determined by purposive sampling and analyzed qualitatively through analytical naration, graphs and tables.

The policies regarding dental health care waste managements in Semarang City are found in the standard operational procedure of licensing. The procedures are held in publishing the operational license for clinics and the professional license for dentists. From a juridical point of view, a legal vacuum regarding obligation of environmental document and overlapping guidelines in both of ministry's regulation impact both of health care facilities carry out the procedure inappositely. The local government should publish the local guidelines, form letters, or decrees as a quick alternative way to suspend those juridical inhibitions. The licensing procedures act as a sociological support factor for clinic and independent dentist practices to renew their mou with the third parties every year. The lack of knowledge about health care waste ministry's guidelines inhibit the implementations in those facilities. PDGI Semarang could tahe the role in educating their peers through local seminars or as a material to be discussed at their regular meeting. Technically, the absence of temporary storage and cold srorage make the health care waste unsave to be kept. It is also quite expensive for dentists having cooperation personally with legal third parties. Regarding to these factors, it is wise for local government start planning to build their own hazardous waste management center.
\end{abstract}

Keyword: Policies, Health care waste, Dental service, Clinic, Dentists

Abstrak: Potensi produksi limbah medis meningkat seiring dengan bertambahnya jumlah fasilitas pelayanan kesgilut di kota Semarang. Jika tidak dikelola dengan benar, tentu akan berisiko menyebarkan infeksi dan mencemari lingkungan hidup. Pengelolaan limbah medis tidak hanya berkaitan dengan kesehatan dan teknis lingkungan, tetapi juga regulasi yang berlaku. Oleh karena itu, peran Pemkot Semarang sebagai regulator menjadi penting. Penelitian ini bertujuan untuk menganalisis mengenai kebijakan Pemerintah Kota Semarang, pelaksanaan pengelolaan, serta mengidentifikasi faktor pendukung dan penghambat di klinik dan dokter gigi praktik mandiri.

Penelitian dilakukan dengan metode yuridis sosiologis dan dipaparkan secara deskriptif analitis. Data primer dikumpulkan melalui studi lapangan dengan cara observasi dan wawacara. Data 
hukum sekunder diperoleh penulis melalui studi pustaka dengan mengumpulkan teori hokum, regulasi dan kebijakan pemerintah pusat hingga daerah yang relevan, sistem pelayanan kesehatan gigi mulut, serta teknis lingkungan. Sampel penelitian diambil secara purposive dari populasi klinik yang menjalankan pelayanan kesgilut serta dokter gigi praktik mandiri di Kota Semarang. Data penelitian kemudian dianalisis secara kualitatif dan dijelaskan melalui narasi analitis, diagram, dan tabel.

Secara umum, kebijakan Pemkot Semarang dalam pengelolaan limbah medis ditemukan di tingkat klinik maupun dokter gigi praktik mandiri. Kebijakan Pemkot Semarang ada dalam bentuk SPO penerbitan izin operasional klinik dan surat izin praktik dokter gigi. Namun, implementasinya terhambat karena terdapat overlapping dari isi pedoman KLHK dengan Kemenkes, serta adanya kekosongan hukum dalam perda lingkungan terkait kategori kepemilikan dokumen lingkungan. Diskresi yang diberikan untuk klinik menjadi tidak tepat karena ada amanah regulasi yang belum terpenuhi. Surat edaran atau surat keputusan Walikota dapat diterbitkan sebagai langkah cepat dalam menyelesaikan hambatan yuridis ini. Pemkot Semarang telah memberikan paksaan administratif bagi klinik berupa kewajiban memiliki dokumen lingkungan dan dokumen kerja sama dengan pihak ketiga. Namun implementasinya di klinik masih menemui hambatan yakni waktu pengangkutan limbah medis oleh pihak ketiga belum sesuai ketentuan. Ketersediaan TPS berizin dan cold srorage di klinik menjadi solusi praktis dari hambatan ini. Pemkot Semarang masih menghimbau dokter gigi praktik mandiri untuk bekerja sama dengan pihak ketiga. Biaya kerja sama dengan pihak ketiga yang relatif mahal menyebabkan dokter gigi enggan bekerja sama. Akan lebih baik jika Pemkot Semarang membangun fasilitas pengelolaan limbah medis untuk mengelola hasil limbah medis yang dihasilkan di wilayahnya.

Kata kunci: Kebijakan, Limbah Medis, Kesgilut, Klinik Gigi, Dokter Gigi

\section{PENDAHULUAN}

Tujuan pembangunan nasional di bidang kesehatan adalah mewujudkan kesehatan masyarakat setinggi-tingginya. Untuk mencapai derajat kesehatan tersebut, upaya kesehatan perlu dilakukan secara terpadu dan berkesinambungan. Sesuai dengan amanat Undang-Undang Dasar 1945, segala kebijakan, tindakan pemerintah, maupun pembangunan harus tunduk pada hak asasi manusia atas lingkungan hidup yang baik dan sehat. ${ }^{1}$ Penyelenggaraan pembangunan kesehatan pun harus ikut memperhatikan aspek lingkungan hidup. Penyelenggaraan upaya kesehatan melibatkan segenap sumber daya bidang kesehatan yakni dana, tenaga, perbekalan kesehatan, sediaan farmasi, alat kesehatan, teknologi dan fasilitas pelayanan kesehatan. Segala aktivitas yang dilakukan pasti akan menimbulkan dampak bagi lingkungan sekitar. Sebagaimana manusia sangat membutuhkan lingkungan, pengelolaan kesehatan lingkungan dalam lingkup pembangunan bidang kesehatan tentunya menjadi unsur yang tidak dapat dilepaskan. Di dalam Pasal 163 ayat (1) Undang-Undang Nomor 36 Tahun 2009 tentang Kesehatan mengamanatkan bahwa Pemerintah Pusat, Pemerintah Daerah dan masyarakat menjamin ketersediaan lingkungan yang sehat dan tidak mempunyai risiko buruk bagi kesehatan. Dengan demikian, tanggung jawab mewujudkan lingkungan yang sehat pun juga ada pada semua pelaku kesehatan. Salah satu aspek dalam rangka mewujudkan lingkungan yang sehat adalah melakukan pengelolaan limbah pelayanan kesehatan. Limbah pelayanan

\footnotetext{
${ }^{1}$ Eko Nurmandiansyah, Eco-Philosophy dan Implikasinya Dalam Politik Hukum Lingkungan Di Indonesia, 2014, Melintas, Vol. 30(1), hlm 70-104.
} 
kesehatan berbeda dengan limbah produksi lainnya. Oleh karena itu, untuk mengelola limbah pelayanan kesehatan memerlukan prosedur tersendiri. ${ }^{2}$

Kasus maraknya temuan limbah medis padat infeksius di sejumlah wilayah mulai muncul di media massa sejak tahun 2017. Temuan limbah medis padat infeksius yang terbuang sembarangan ditemukan di berbagai daerah di Indonesia. Limbah padat infeksius seperti jarum suntik, botol kaca yang terkontaminasi darah ditemukan berserakan dan berbaur dengan sampah rumah tangga di Tempat Pembuangan Sampah di Cirebon pada tahun 2017. ${ }^{3}$ Pada tahun 2018, lima puluh kantong plastik kuning dengan berat masing-masing $10 \mathrm{~kg}$ berisi limbah padat yang terkontaminasi darah ditemukan di kawasan mangrove Dusun Kepuh, Karawang. Sampah ini bercampur dengan limbah non medis seperti puluhan kantong medis dan nota rumah sakit. ${ }^{4}$ Di wilayah Kabupaten Semarang, limbah medis padat ditemukan oleh warga di Sungai Lodoyong, Ambarawa pada Januari 2018. Limbah medis padat yang ditemukan antara lain spet suntikan, kain kasa, kapas, beberapa ampul obat injeksi, serta botol habis periksa darah botol kecil'5. Sebagai tindak lanjut temuan limbah medis padat di Ambarawa, Dinas Kesehatan Kabupaten Semarang melalui Bidang Pengendalian dan Pemberantasan Penyakit membentuk tim untuk melakukan investigasi. Investigasi dilakukan untuk memastikan dampak infeksi pada masyarakat dari sampah medis tersebut. Kondisi ini menimbulkan keprihatinan para pelaku kesehatan dan juga masyarakat.

Limbah pelayanan kesehatan merupakan material sisa hasil dari kegiatan pelayanan kesehatan di fasilitas pelayanan kesehatan ${ }^{6}$. Limbah pelayanan kesehatan secara umum dikategorikan menjadi 2 yakni: limbah medis dan limbah non medis. Komite Pencegahan dan Pengendalian Infeksi membagi limbah pelayanan kesehatan menjadi limbah infeksius dan limbah non infeksius ${ }^{7}$. Limbah non medis bersumber dari sisa buangan dapur, rumah tangga, maupun limbah perkantoran. Limbah medis pelayanan kesgilut umumnya menghasilkan 2 kategori limbah yakni berupa limbah cair dan limbah padat. ${ }^{8}$ Limbah cair yang dihasilkan dari pelayanan kesehatan gigi bisa berupa darah dan saliva pasien, larutan desinfektan untuk sterilisasi (klorin, hydrogen peroksida, surfaktan), larutan irigasi saluran akar (sodium hipoklorit, EDTA, saline, klorheksidin), dan larutan medikamen saluran akar (formokresol, ChKm, TKF). Selanjutnya, limbah medis padat yang dihasilkan dari dokter gigi praktik mandiri di kota Semarang dapat dibagi menjadi:

1. alat pelindung diri sekali pakai (APD): masker dan sarung tangan yang umumnya sudah terkontaminasi darah dan cairan mulut pasien.

2. bahan balutan: kassa potong, tampon, cotton roll, dan cotton pellet (umumnya sudah terkontaminasi darah dan cairan mulut pasien).

\footnotetext{
2 Rosihan Adhani, 2018, Pengelolaan Limbah Medis Pelayanan Kesehatan, Banjarmasin: Penerbit Pusaka Banua, hlm 1-2.

3 Muhamad Syahri Romdhon, Limbah Medis Berserakan di Tempat Pembuangan Sampah di Cirebon, diakses tanggal 25 April 2019, https://regional.kompas.com/read/2017/12/06/22291671/limbah-medis-berserakan-ditempat-pembuangan-sampah- di-cirebon, Kompas.com.

4 Michael Hangga Wismabrata, 4 Fakta di Balik Tumpukan Kantong Plastik Limbah Medis di Karawang, diakses tanggal 25 April 2019, https://regional.kompas.com/read/2018/09/10/06024971/4-fakta-di-balik-tumpukankantong-plastik-limbah- medis-di-karawang, Kompas.com.

5 Eko Susanto, Dinkes Semarang Bentuk Tim Terkait Temuan Sampah Medis, diakses tanggal 10 Mei 2019, Ambarawa, https://news.detik.com/berita-jawa-tengah/d-3812602/dinkes-semarang-bentuk-tim-terkaittemuan-sampah-medis, detikNews.com.

${ }^{6}$ Rosihan Adhani, Op.Cit., hlm 5.

7 Ibid

8 Ibid, hlm 52.
} 
3. benda tajam: jarum suntik, scalpel blade, pecahan ampul obat anestesi, dan jarum endodontik.

4. medikamen perawatan saluran akar dan pasta devitalisasi

5. bahan tumpatan: glass ionomer cement, resin komposit, dan amalgam

6. gigi pasca pencabutan dan jaringan-jaringan rongga mulut hasil eksisi maupun kuretase, deposit kotoran padat dari dental unit (karang gigi dan deposit rongga mulut lainnya di filter).

7. bahan sisa perawatan: bahan cetak, bur gigi yang sudah aus, mata scaler yang sudah rusak.

Jumlah limbah medis padat sangat bervariasi tergantung dari banyaknya jumlah pasien yang dilayani dalam satu periode waktu. Dokter gigi praktik mandiri di kota Semarang yang berpraktik

lima hari kerja selama seminggu dengan jumlah rata-rata pasien per bulan 97 pasien dapat menghasilkan limbah medis padat B3 rata-rata sebanyak 3,78 kg per bulan. ${ }^{9}$

Limbah medis merupakan bagian dari limbah B3 yang sebetulnya sudah diatur oleh Pemerintah. Terminologi limbah medis telah dikenal di dalam lampiran Peraturan Menteri Lingkungan Hidup dan Kehutanan No. P56/MENLHK-SETJEN/2015 tentang Tata Cara dan Persyaratan Teknis Pengelolaan Limbah Bahan Berbahaya dan Beracun dari Fasilitas Pelayanan Kesehatan. Dengan demikian, limbah medis dapat dianalogikan sebagai bagian dari limbah B3 hasil pelayanan di fasilitas pelayanan kesehatan. Walikota Semarang telah mengatur mengenai limbah B3 dalam Peraturan Daerah Kota Semarang Nomor 13 Tahun 2006 tentang Lingkungan Hidup. Di dalam Pasal 33 dinyatakan bahwa "Setiap penanggungjawab usaha dan/atau kegiatan yang menggunakan bahan dan/atau menghasilkan limbah B3 wajib melakukan pengelolaan dan pencegahan terjadinya pencemaran ke dalam lingkungan sesuai dengan Peraturan Perundang- Undangan". Oleh karena itu, fasilitas pelayanan kesgilut di Kota Semarang sebagai penghasil limbah medis seharusnya wajib melakukan pengelolaan limbah medis.

Kegiatan yang berpotensi menghasilkan limbah B3 di Kota Semarang telah diatur di dalam Perda Kota Semarang No 13 Tahun 2006 Tentang Pengendalian Lingkungan Hidup. Pasal 50 ayat (1) menegaskan bahwa setiap usaha maupun kegiatan yang berpotensi menimbulkan dampak lingkungan hidup wajib mendapatkan izin dari Walikota. Jenis kegiatan yang memerlukan izin lingkungan diuraikan di dalam pasal 50 ayat (3) diantaranya penghasil limbah B3 dan penyimpanan sementara limbah B3. Namun pelaksanaan mengenai perizinan ini belum diberlakukan secara tepat bagi fasyankes primer khususnya klinik dan dokter gigi praktik mandiri di kota Semarang. Padahal perizinan ini merupakan bagian dari tindakan pengawasan yang dilakukan oleh Pemkot Semarang.

Hal ini membawa dampak bagi kegiatan pengelolaan limbah medis di fasyankes yang belum sesuai ketentuan perundang-undangan.

Sejak tahun 2014 hingga 2019, jumlah fasyankes terus mengalami peningkatan. Berdasarkan Profil Kesehatan Kota Semarang tahun 2019, jumlah rumah sakit di kota Semarang mencapai 27 rumah sakit. Puskesmas di kota Semarang mencapai 37 puskesmas. ${ }^{10}$

\footnotetext{
9 Survei dilakukan di Kota Semarang pada tanggal 5 April 2019 wawancara dengan salah satu dokter gigi yang berpraktik mandiri di Kota Semarang

10 Dinas Kesehatan Kota Semarang. Profil Kesehatan Kota Semarang 2019, diakses tanggal 20 Juli 2020, https://dinkes.semarangkota.go.id/asset/upload/Profil/Profil/Profil\%20Kesehatan \%202019.pdf, hlm 12.
} 
Berdasarkan data DKK terbaru Maret 2020, klinik di kota Semarang berjumlah 274 klinik yang terdiri dari 228 klinik pratama dan 46 klinik utama. Sebanyak 29\% dari jumlah klinik pratama memberikan pelayanan kesgilut. Sebanyak 31\% dari klinik utama merupakan klinik gigi. Jumlah dokter gigi praktik di Kota Semarang ada sebanyak 721 dokter gigi. Sebanyak 128 dokter gigi membuka praktik mandiri. ${ }^{11}$ Profil ini menunjukkan bahwa ketersediaan fasyankes di kota Semarang sudah berkembang pesat. Jumlah klinik dan dokter gigi praktik mandiri pun lebih banyak dibandingkan dengan puskesmas maupun rumah sakit. Pelayanan kesgilut sebagian besar adalah tindakan medis yang mana sudah pasti menghasilkan limbah medis yang lebih banyak dibandingkan dengan rawat jalan pelayanan kesehatan poli umum atau dokter umum. Berdasarkan uraian sebelumnya mengenai rerata jumlah limbah medis yang dihasilkan oleh dokter gigi praktik mandiri bisa dilihat betapa besar potensi limbah medis yang dihasilkan. Melihat potensinya yang besar dan mempertimbangkan dampak serta risiko yang mungkin terjadi, peran pemerintah dan fasyankes dalam mengelola limbah medis menjadi hal sangat penting.

Penelitian mengenai pelaksanaan pengelolaan limbah medis pelayanan kesgilut di klinik dan dokter gigi praktik mandiri sudah pernah dilakukan sebelumnya. Penulis menemukan dua penelitian terkait manajemen pengelolaan limbah medis pelayanan kesgilut. Pertama, penelitian kualitatif yang dilakukan Dewa Ayu, berjudul "Manajemen pengelolaan limbah medis di praktik dokter gigi di Kabupaten Tabanan". Penelitian tersebut menunjukkan bahwa para dokter gigi belum melaksanakan pengelolaan limbah medis sesuai standar, yakni tidak memiliki standar prosedur operasional pengelolaan limbah medis, sarana yang kurang memadai, belum menjalin kerja sama dengan pihak ketiga, dan kurangnya pengawasan dari Dinas Kesehatan setempat. ${ }^{12}$

Penelitian kedua dilakukan oleh Rurie Marita Suryadewi yang berjudul "Analisis Manajemen Pengelolaan Limbah Pelayanan Kesehatan Gigi (Studi Kasus pada RS X, Puskesmas Pancoran, Puskesmas Pejaten Barat, dan Klinik Gigi TADC). Fokus penelitian ini adalah mengevaluasi kesesuaian manajemen pengelolaan limbah medis dengan kaidah pengelolaan limbah medis yang benar, terutama pengelolaan limbah amalgam (mengandung merkuri) sebagai salah satu bahan tumpatan gigi. Dasar regulasi yang diacu adalah Environmental Regulations and Dental Office of Ohio Environmental Protection Agency dan KEPMENKES 1204/MENKES/SK/2004 tentang Persyaratan Kesehatan Lingkungan Rumah Sakit. Dari hasil penelitian kualitatif yang sudah dilakukan menunjukkan bahwa manajemen limbah pelayanan kesehatan gigi di fasyankes yang diteliti belum sesuai dengan peraturan yang berlaku. ${ }^{13}$ Sejauh ini pengolahan limbah medis baru sampai pada pemilahan limbah padat dan selanjutnya dikelola oleh pihak ketiga. sedangkan pengelolaan limbah cair infeksius dan amalgam masih belum dilakukan. Pengelolaan limbah cair infeksius belum dilakukan karena responden tidak semua memiliki Instalasi Pengelolaan Air Limbah (IPAL).

Melihat uraian diatas, pelayanan kesgilut di fasyankes merupakan suatu bentuk perbuatan hukum yang hasilnya menimbulkan akibat hukum dalam bentuk hasil tindakan medis dan

\footnotetext{
${ }^{11}$ Data didapatkan dari wawancara dengan Bidang Sumber Daya Kesehatan DKK Semarang pada tanggal 24 April 2020.

${ }^{12} 12$ Dewa Ayu Putu Gek Mega Suryasih Putri, dkk, "Manajemen Pengelolaan Limbah Medis Praktik Dokter Gigi Kabupaten Tabanan", 2018, Bali Dental Journal, Vol.2, No.1, hlm 9-16.

${ }^{13}$ Rurie Marita Suryadewi, "Analisis Manajemen Pengelolaan Limbah Pelayanan Kesehatan Gigi (Studi Kasus pada KlinikThe Aesthetic Dental \& Skin Clinic, RS. Tri Dipa, Puskesmas Pancoran, dan Puskesmas Pejaten Barat)", Tesis: Program Studi Ilmu Kesehatan Masyarakat, Program Pascasarjana Fakultas Kesehatan, Yogyakarta, 2016, hlm 37-55.
} 
limbah hasil pelayanan. Pemerintah Kota Semarang, dalam sudut pandang hukum, perlu berperan aktif karena berkedudukan sebagai regulator, pembuat kebijakan, dan pengawas. Dilihat dari sudut pandang kesehatan, pengelolaan limbah medis yang kurang tepat dapat memberi dampak negatif. Potensi bahaya sudah dapat muncul sejak tahap pengumpulan, penampungan, pengangkutan, pemusnahan, hingga pembuangan. Di dalam lingkungan fasyankes, limbah medis dapat menjadi sumber terjadiya infeksi silang dan menimbulkan kecelakaan kerja maupun penyakit akibat kerja. Pelaksanaan pengelolaan limbah medis tidak hanya bergantung pada teknis pengelolaan lingkungan saja tetapi juga dipengaruhi oleh hukum yang berlaku, situasi politik dan ekonomi suatu daerah, juga sistem kesehatan yang berjalan ${ }^{14}$. Regulasi mengenai limbah medis sebagai bagian dari limbah B3 di Indonesia telah ada dalam bentuk peraturan pemerintah, undang-undang, dan peraturan menteri. Pelaksanaannya di lapangan tentu menimbulkan banyak kendala terlebih dalam lingkup daerah khususnya kota Semarang. Kebijakan merupakan salah satu cara untuk mengatasi hambatan yang ditemukan dari sisi regulasi tersebut. Oleh karena itu, penulis tertarik untuk meneliti “Kebijakan Pemerintah Kota Semarang Dalam Pengelolaan Limbah Medis Klinik Gigi Dan Dokter Gigi Praktik Mandiri”.

\section{PERUMUSAN MASALAH}

Berdasarkan latar belakang penelitian yang telah dikemukakan berkaitan dengan Kebijakan Pemerintah Kota Semarang Dalam Pengelolaan Limbah Medis Klinik Gigi Dan Dokter Gigi Praktik Mandiri", dapat disusun rumusan masalah dalam penelitian ini dalam bentuk pertanyaan sebagai berikut:

1. Bagaimana kebijakan Pemerintah Kota Semarang dalam mengatur pengelolaan limbah medis di Klinik Gigi dan Dokter Gigi Praktik Mandiri?

2. Bagaimana pelaksanaan pengelolaan limbah medis di Klinik Gigi dan Dokter Gigi Praktik Mandiri?

3. Faktor-faktor apa saja yang mendukung dan menghambat pelaksanaan kebijakan Pemerintah Kota Semarang dalam pengelolaan limbah medis di Klinik Gigi dan Dokter Gigi Praktik Mandiri?

\section{METODE PENELITIAN}

Penelitian ini menerapkan metode pendekatan yuridis sosiologis. Metode pengumpulan data dilakukan melalui studi lapangan dan studi pustaka. Studi lapangan dilaksanakan untuk mendapatkan data primer melalui observasi dan wawancara. Observasi dilakukan dengan mengamati setiap bentuk kebijakan yang dikeluarkan, entah dalam bentuk buku panduan, surat edaran, standar prosedur operasional, surat keputuan, maupun memo yang dikeluarkan Pemkot Semarang di Dinas Kesehatan dan Dinas Lingkungan Hidup Kota Semarang. Observasi mengenai pelaksanaan pengelolaan limbah medis diamati mulai dari penghasilan limbah, pemilahan limbah, penyimpanan sementara limbah, hingga pengolahan limbah. Wawancara dilakukan untuk mendapatkan informasi yang lebih mendalam mengenai kebijakan yang dikeluarkan Pemkot Semarang, pelaksanaan pengelolaan limbah medis, serta faktor-faktor yang mendukung dan menghambat.

\footnotetext{
${ }^{14}$ M. Caniato, et al., "International Governance Structures for Health-Care Waste Management: A Systematic Review of Scientific Literature", 2015, Journal of Environmental Management, Vol. 153, hlm 93-107
} 
Narasumber dari wawancara penelitian ini antara lain: Dinas Kesehatan Kota Semarang, Dinas Lingkungan Hidup Kota Semarang, pemilik atau penanggungjawab klinik, petugas pengelola limbah medis di klinik, dan dokter gigi praktik mandiri di kota Semarang. Studi pustaka dilakukan untuk mendapatkan data sekunder berupa bahan hukum primer, sekunder, dan tersier. Bahan hukum primer penulis kumpulkan dari semua peraturan perundang-undangan yang terkait. Bahan hukum sekunder yang digunakan dalam penelitian ini antara lain buku metodologi penelitian hukum, buku teori ilmu hukum, buku hukum administrasi negara, buku kebijakan publik, buku tentang fasyankes, buku limbah medis, jurnal hukum, jurnal kesehatan, serta laporan-laporan lain yang relevan dengan penelitian ini. Bahan hukum tersier yang digunakan dalam penelitian ini adalah kamus besar bahasa Indonesia. Dalam penelitian ini, sampel penelitian ditentukan secara purposive sampling. Sampel dipilih sebanyak tiga klinik dan lima dokter gigi praktik mandiri di Kota Semarang. Kriteria inklusi untuk sampel penelitian ini antara lain: klinik pratama atau utama milik swasta murni, milik TNI/POLRI, atau milik perusahaan yang memiliki pelayanan kesgilut dan dokter gigi praktik mandiri general practitioner atau spesialis (spesialis ortodonsia, konservasi gigi, atau bedah mulut); bekerja sama dengan BPJS Kesehatan maupun yang tidak; serta lokasinya berada dalam wilayah PDGI kota Semarang. Semua data yang dikumpulkan tersebut kemudian dianalisis secara kualitatif untuk menggambarkan kenyataan yang terjadi, hubungan sebab-akibat, peranan nilai, dan kemungkinan generalisasi. Hasil analisis ini kemudian penulis ungkapkan secara deskriptif analitis melalui narasi.

\section{PEMBAHASAN}

\section{Kebijakan Pemerintah Kota Semarang Dalam Mengatur Pengelolaan Limbah Medis di Klinik Gigi Dan Dokter Gigi Praktik Mandiri}

\section{a. Subjek Dalam Kebijakan Pemerintah Kota Semarang dalam Pengelolaan Limbah Medis}

Pemerintah disini merupakan subjek hukum yang melaksanakan peran kaitannya dengan kebijakan pengelolaan limbah medis. Sebagaimana yang dikatakan oleh SF Marbun dan Moh.

Mahfud MD, pemerintah merupakan suatu alat perlengkapan negara yang memiliki peran melaksanakan urusan pemerintahan. Pemerintah yang dimaksud adalah badan eksekutif. Dalam melaksanakan kinerjanya, pemerintah sebagai badan eksekutif memiliki struktur berjenjang. Hal tersebut selaras dengan pernyataan Diana Halim Koentjoro yang menegaskan adanya asas desentralisasi sebagai dasar pembagian kekuasaan dimana tampak melalui pemberian kewenangan pemerintah pusat kepada pemerintah daerah. Di tingkat daerah, badan eksekutif ini merupakan struktur yang menjalankan pemerintahan daerah mulai dari kepala daerah hingga jajaran di bawahnya. Hal ini pun tercantum dalam pengertian pemerintah daerah yang tercantum di dalam UU No. 23 Tahun 2014 tentang Pemerintah Daerah. Pemerintah daerah adalah kepala daerah dalam hal ini Gubernur, Bupati, atau Walikota. Kepala daerah tingkat kota adalah Walikota, maka kepala daerah kota Semarang adalah Walikota Semarang.

Walikota Semarang dalam menyelenggarakan tugas pemerintahan dibantu oleh perangkat daerah. Sebagaimana yang disebutkan dalam Perda Kota Semarang No. 14 Tahun 2016, perangkat daerah merupakan unsur pembantu Walikota dalam penyelenggaraan urusan pemerintahan yang menjadi kewenangan daerah. Salah satu 
perangkat daerah adalah dinas daerah. Penyelenggaraan urusan bidang kesehatan didelegasikan kepada Dinas Kesehatan Kota Semarang. Penyelenggaraan urusan bidang lingkungan hidup didelegasikan kepada Dinas Lingkungan Hidup Kota Semarang. Menurut Perwal No. 70 Tahun 2019, beberapa pelayanan perizinan dan non perizinan pun telah didelegasikan kepada Dinas Penanaman Modal dan Pelayanan Terpadu Satu Pintu.

\section{b. Tugas Pemerintah Kota Semarang dalam Pengelolaan Limbah Medis}

Pembagian kekuasaan yang terjadi mengakibatkan terjadinya pembagian urusan pemerintahan dari pusat kepada daerah. Sebagaimana dikatakan oleh Ardiyan Saptawan dan Philipus M. Hadjon dalam teorinya mengenai prinsip otonomi pemerintahan daerah, Pemkot Semarang dapat secara mandiri dan bebas mengatur rumah tangganya. Selain itu, Pemkot Semarang juga mampu melaksanakan pembangunan secara lokal, melaksanakan pelayanan publik, serta memberdayakan warganya. Namun, kebebasan ini tidak sepenuhnya diberikan kepada Pemkot Semarang. Pemerintah pusat dapat memberikan penugasan tertentu kepada pemerintah kabupaten/kota. $M$ Solly Lubis dalam teorinya mengenai asas penyelenggaraan pemerintah menyatakan bahwa ada asas lain yakni asas dekonsentrasi. Melalui asas dekonsentrasi, Pemkot Semarang melaksanakan tugas yang diberikan oleh pemerintah pusat dengan pertanggungjawaban akhir ada pada Pemkot Semarang itu sendiri. Dilihat dari regulasinya, pembagian urusan ini tercantum di dalam lampiran UU No. 23 Tahun 2014 Tentang Pemerintahan Daerah yang mana bidang kesehatan dan lingkungan hidup turut masuk di dalamnya. Namun secara prinsip, apapun urusan pemerintahan yang dikerjakan, Pemkot Semarang tetap harus mengedepankan kepentingan warganya. Sebagaimana yang disampaikan oleh Utrecht dalam teorinya mengenai administrasi negara, tugas utama pemerintah adalah mewujudkan kesejahteraan umum. Banyak cara yang bisa dilakukan untuk mewujudkannya. Pemerintah Kota Semarang berwenang mengeluarkan keputusan berkaitan dengan kebijakan atau mengeluarkan ketentuan umum sebagaimana yang dikatakan oleh Prajudi Atmosudirjo dalam teorinya mengenai tugas pemerintah. Walikota Semarang telah mengeluarkan ketentuan umum mengenai lingkungan hidup dan limbah B3 dalam Perda Kota Semarang No. 13 Tahun 2006 Tentang Pengendalian Lingkungan Hidup.

Ridwan HR dalam teorinya mengenai perbuatan pemerintah menyatakan bahwa kegiatan yang dilakukan pemerintah merupakan bagian dari perbuatan hukum yang menimbulkan akibat hukum. Akibat hukum yang dihasilkan adalah hak dan kewajiban, dimana semuanya itu tertuang dalam kewenangan Pemkot Semarang dalam melakukan perbuatan hukum. Oleh karena hak Pemkot Semarang sebagai subjek hukum yakni melaksanakan kewenangan yang sudah diberikan oleh peraturan perundang-undangan, maka ia dapat menuntut warganya untuk melakukan sesuatu ataupun tidak melakukan sesuatu. Sebaliknya, Pemkot Semarang memiliki tugas untuk memenuhi kewajibannya sebagaimana tercantum dalam peraturan perundangundangan.

\section{c. Kewenangan Pemerintah Kota Semarang dalam Pengelolaan Limbah Medis}

Pemerintah Kota Semarang memiliki wewenang yang sah dengan berdasar hukum untuk dapat melaksanakan urusan pemerintah, seperti yang diutarakan oleh Philipus M. Hadjon dalam teorinya mengenai kewenangan. Kewenangan yang dimaksudkan tersebut juga mencakup bidang kesehatan dan lingkungan hidup. Kewenangan 
Pemkot Semarang bidang lingkungan hidup dan kesehatan, sebagaimana disebutkan dalam teori kewenangan menurut Murtir Jeddawi, diberikan secara atributif oleh undang-undang. Hal ini diatur di dalam lampiran UU No. 23 Tahun 2014. Kewenangan Pemkot Semarang yang kaitannya dengan lingkungan hidup sub bidang B3 yakni perihal penyimpanan sementara limbah B3, pengumpulan limbah B3 dalam wilayah Kota Semarang, serta pembinaan dan pengawasan terhadap usaha/kegiatan yang izin lingkungannya diterbitkan oleh Pemkot Semarang. Beberapa kewenangan Pemkot Semarang bidang kesehatan yakni pengelolaan upaya kesehatan perorangan tingkat kota serta penerbitan izin praktik tenaga kesehatan.

Pasal 2 ayat (2) Perda Kota Semarang No. 5 Tahun 2008 Tentang Urusan Pemerintahan Yang Menjadi Kewenangan Pemerintahan Daerah Kota Semarang menegaskan bahwa bidang kesehatan dan lingkungan hidup merupakan urusan wajib yang menjadi kewenangan Pemerintah Kota Semarang. Penyelenggarakan urusan pemerintahan bidang kesehatan dan lingkungan hidup didelegasikan oleh Walikota kepada dinas daerah. Menurut Perda Kota Semarang No. 14 Tahun 2016, dinas daerah yang ditunjuk yakni DLH Kota dan DKK. Sebagaimana dikatakan oleh Jimly Asshidiqie dalam teorinya mengenai kewenangan, kedua dinas ini berwenang untuk mengambil keputusan terkait pelaksanaan tugasnya sesuai dengan peraturan perundang-undangan dan bertanggung jawab atas keputusannya. Kedudukan kedua dinas ini ada di dalam Perwal No. 72 Tahun 2016 tentang Kedudukan, Susunan Organisasi, Tugas dan Fungsi, serta Tata Kerja Dinas Lingkungan Hidup Kota Semarang. Tugas dan fungsi kedua dinas ini tercantum di dalam Perwal No. 72 Tahun 2016 dan Perwal No. 62 Tahun 2016 sebagaimana yang telah penulis uraikan di dalam gambaran umum objek penelitian.

d. Objek Dalam Kebijakan Pemerintah Kota Semarang dalam Pengelolaan Limbah Medis di Klinik Gigi dan Dokter Gigi Praktik Mandiri

Pengelolaan limbah medis yang dilaksanakan oleh klinik dan dokter gigi praktik mandiri menjadi objek dalam pembahasan tesis ini. Limbah medis termasuk sebagai limbah B3 yang dihasilkan di fasyankes. Sebagai objek hukum, pengelolaan limbah medis telah termanifestasi di dalam regulasi dalam bentuk peraturan perundangundangan yang berlaku di Indonesia.

Pengelolaan limbah medis diatur dalam PP No. 101 Tahun 2014 Tentang Pengelolaan Limbah Bahan Berbahaya dan Beracun. Secara teknis, pedoman pengelolaan limbah medis telah dikeluarkan oleh menteri lingkungan hidup dan kehutanan serta menteri kesehatan. Pedoman pengelolaan limbah medis ada di dalam Peraturan Menteri Lingkungan Hidup dan Kehutanan No. P.56/MENLHK-SETJEN/2015 Tentang Tata Cara dan Persyaratan Teknis Pengelolaan Limbah Bahan Berbaaya dan Beracun Dari Fasilitas Pelayanan Kesehatan dan Peraturan Menteri Kesehatan No. 27 Tahun 2017 Tentang Pedoman Pencegahan Pengendalian Infeksi.

Berdasarkan hasil wawancara yang dilakukan penulis kepada DLH Kota Semarang, ditemukan adanya tumpang tindih dalam regulasi pengelolaan limbah medis antara Kementrian Lingkungan Hidup dan Kementrian Kesehatan. Permasalahan di tingkat pusat ini kemudian muncul di tingkat daerah. Acuan pedoman yang digunakan oleh DLH Kota Semarang dan DKK Semarang berbeda. Di lapangan, DLH Kota Semarang mengacu pada Permen LHK No. 56 Tahun 2015 sedangkan DKK Semarang mengacu pada Permenkes No. 27 Tahun 2017 dan Permenkes No. 9 Tahun 2009. Perbedaan 
acuan regulasi akhirnya menghambat jalannya tugas kedua dinas tersebut di lapangan. Acuan regulasi t ertinggi ada pada PP No. 101 Tahun 2014 Tentang Pengelolaan Limbah Berbahaya dan Beracun. Berdasarkan regulasi tersebut, DLH menilai pengaturan limbah medis yang ada di Permenkes terlalu longgar. Oleh karena fungsi pembinaan dan pengawasan fasyankes merupakan domain DKK, permenkes yang dinilai terlalu longgar tadi menyebabkan pelaksanaan pengelolaan limbah medis di fasyankes menjadi kurang maksimal. Masalah ketidak-sinergi-an ini sebetulnya bisa diselesaikan oleh Walikota selaku Kepala Daerah Kota Semarang. Walikota dapat mengeluarkan instrumen hukum dalam bentuk peraturan atau kebijakan yang dapat menengahi masalah ini.

Sejalan dengan teori mengenai perbuatan hukum pemerintah menurut Lutfi Efendi, Pemkot Semarang sebagai badan pemerintah yang melakukan perbuatan hukum publik memiliki kewenangan mengeluarkan peraturan. Kegiatan mengatur yang dilakukan oleh Pemkot Semarang merupakan bagian dari perbuatan hukum yang mana menurut Prof Sudikno Mertokusumo memiliki tujuan hukum. Tujuan hukum yang ingin dicapai yakni menciptakan ketertiban dan melindungi kepentingan masyarakat Kota Semarang. Pengelolaan limbah medis merupakan bagian dari upaya pengendalian lingkungan hidup yang bertujuan untuk menjamin tersedianya lingkungan yang sehat bagi warga kota Semarang. Pemerintah Kota Semarang telah mengeluarkan Peraturan Daerah Kota Semarang No. 13 Tahun 2006 Tentang Lingkungan Hidup.

Kewajiban mengelola limbah B3 bagi penghasil limbah B3 telah dinyatakan di dalam Perda tersebut. Di dalam Pasal 33 disebutkan bahwa "setiap penanggungjawab kegiatan yang menghasilkan limbah B3 wajib melakukan pengelolaan dan pencegahan terjadinya pencemaran ke dalam lingkungan sesuai dengan peraturan perundang-undangan". Perda tersebut secara tidak langsung sifatnya mengikat warga masyarakat kaitannya dengan pengelolaan limbah B3. Limbah medis itu termasuk limbah B3 sehingga fasyankes sebagai penghasil wajib mengelola limbah medis yang dihasilkannya. Dilihat dari sudut pandang pelayanan kesehatan, pengelolaan limbah medis di fasyankes merupakan bagian dari kegiatan pencegahan dan pengendalian infeksi. Kegiatan ini bertujuan untuk mewujudkan pelayanan kesehatan yang aman bagi pelaksana pelayanan kesehatan dan pasien khususnya dalam hal pencegahan dan pengendalian infeksi. Sebagaimana yang telah penulis uraikan dalam gambaran umum penelitian bahwa potensi limbah medis yang dihasilkan dari pelayanan kesgilut di klinik dan dokter gigi praktik mandiri cukup besar. Hal ini disebabkan oleh jumlah dan kebutuhan masyarakat terhadap pelayanan kesgilut yang semakin meningkat. Apalagi di era pandemi seperti yang dialami oleh Indonesia sekarang. Penggunaan bahan APD sekali pakai juga mengalami peningkatan sehingga meningkatkan produksi limbah medis yang dihasilkan. Oleh karena itu, sejalan dengan teori yang dikemukakan oleh Diana Halim Koentjoro mengenai perbuatan hukum pemerintah, pengelolaan limbah medis di klinik dan dokter gigi praktik mandiri perlu diawasi dan ikut diatur oleh pemkot Semarang.

Pengaturan bisa muncul dalam bentuk kewajiban berbuat maupun pemberian izin berbuat sesuatu. Pasal 50 ayat (1) Perda Kota Semarang No. 13 tahun 2006 menyebutkan bahwa "setiap kegiatan yang berpotensi menimbulkan dampak lingkungan hidup wajib mendapatkan izin dari Walikota". Usaha dan kegiatan yang wajib mendapat izin pada ayat (3) terkait dengan limbah medis meliputi penghasilan, 
pengelolaan, penyimpanan sementara, dan pengangkutan limbah medis. Menurut Pasal 61 Perda Kota Semarang No. 13 Tahun 2006, Walikota mewajibkan pelaku kegiatan untuk menyusun SPPL apabila kegiatan yang dijalankan memberikan potensi dampak yang kecil terhadap lingkungan hidup. Di dalam penjelasan Pasal 61 Perda Kota Semarang No. 13 Tahun 2006, penilaian ini didasarkan pada kapasitas kegiatan, karakteristik limbah, serta volume limbah yang dihasilkan. Fasyankes sebagai penghasil limbah medis telah diwajibkan untuk memiliki dokumen lingkungan. Dengan demikian, perizinan adalah salah satu upaya konkret Pemkot Semarang untuk mengawasi jalannya kegiatan pengelolaan limbah medis di fasyankes.

Pengelolaan limbah medis di fasyankes ditinjau dari sudut pandang yuridis masih menimbulkan beberapa permasalahan. Poin penting pertama adalah masalah perizinan. Perizinan disini akan berpegaruh pada kegiatan pengelolaan limbah medis yang dilakukan. Di dalam semua regulasi mengenai pengelolaan limbah medis, mulai PP 101 Tahun 2014, Permen LHK No. 56 Tahun 2015, Permenkes No. 27 Tahun 2017, dan Perda Kota Semarang No. 13 Tahun 2006 mewajibkan fasyankes wajib memiliki izin lingkungan. Hal ini disebabkan oleh hasil aktivitas pelayanan kesehatan adalah limbah medis yang mana merupakan bagian dari limbah B3. Setiap kegiatan usaha memiliki izin lingkungan yang berbeda-beda tergantung dari potensi dampak yang terjadi terhadap lingkungan. Pedoman perizinan lingkungan secara rinci dijabarkan dalam Permen LHK No. 13 Tahun 2010 tentang Upaya Pengelolaan Lingkungan Hidup dan Upaya Pemantauan Lingkungan Hidup dan Surat Pernyataan Kesanggupan Pengelolaan dan Pemantauan Lingkungan Hidup. Didalamnya terdapat matriks penentuan dan penapisan kriteria kegiatan usaha seperti apa yang wajib Amdal, UKLUPL, maupun SPPL. Menurut Pasal 3, jenis usaha tersebut ditetapkan oleh Gubernur atau Bupati/Walikota berdasarkan penapisan. Namun, di Kota Semarang penentuan jenis usaha apa saja yang wajib UKL-UPL maupun SPPL belum diatur oleh Walikota. Dengan demikian, menurut penulis terdapat kekosongan hukum dalam hal penerbitan izin lingkungan di Kota Semarang.

Masalah yang menjadi poin penting kedua yakni perihal pengelolaan limbah medis di fasyankes. Setiap limbah medis hasil pelayanan kesgilut tidak dapat dibuang begitu saja ke lingkungan ataupun diperlakukan seperti sampah rumah tangga. Penghasil memiliki kewajiban untuk menyimpan sementara di tempat yang aman hingga akhirnya nanti dikelola lebih lanjut oleh pihak ketiga. Penyimpanan sementara limbah medis menjadi penting mengingat risiko yang mungkin terjadi. Sebagian besar limbah medis yang dihasilkan adalah limbah infeksius. Jika limbah infeksius tidak disimpan dengan aman terdapat risiko penyebaran mikroorganisme patogen yang berasal dari penyakit menular. Jika dikaitkan dengan masa pandemi ini tentu, limbah medis yang dihasilkan dapat menjadi sumber penularan virus Covid-19.

Regulasi mengenai ketersediaan TPS ada di dalam PP No. 101 Tahun 2014, Permen LHK No. 56 Tahun 2015, dan Pemenkes No. 27 Tahun 2017. Berdasarkan wawancara yang dilakukan penulis bersama DLH Kota Semarang, kewajiban memiliki TPS limbah B3 diperuntukkan bagi kegiatan yang memiliki dokumen lingkungan setingkat UKL-UPL. Dokumen SPPL pada intinya hanya merupakan surat pernyataan kesanggupan mengelola lingkungan. Limbah medis yang merupakan bagian dari limbah B3 memerlukan pengelolaan khusus yang mana menurut penulis memerlukan instrumen kontrol yang lebih tegas dari yang ada di SPPL. Salah satunya adalah perihal 
ketersediaan TPS limbah B3 di klinik. Maka, untuk memenuhi hal tersebut, menjadi tidak tepat jika dokumen lingkungan yang wajib dipenuhi oleh klinik adalah SPPL.

\section{e. Kebijakan Pemerintah Kota Semarang Dalam Pengelolaan Limbah Medis Di Klinik} Gigi Dan Dokter Gigi Praktik Mandiri

Pemerintah telah mengambil sikap tegas bahwa segala kegiatan yang berpotensi memberi dampak pada lingkungan harus diatur. Di tingkat pusat, hal ini secara tegas diatur di dalam UU No. 32 Tahun 2009 Tentang Perlindungan dan Pengelolaan Lingkungan Hidup. Kegiatan pelayanan kesehatan yang dijalankan akan menghasilkan limbah medis. Sebagaimana yang dikatakan oleh Herabudin dalam teorinya mengenai kebijakan, pemerintah mengeluarkan kebijakan bahwa pengelolaan limbah medis ini merupakan bagian dari kegiatan pengendalian lingkungan demi keamanan bersama. Oleh karena itu, pemerintah secara konkrit perlu mengeluarkan pedoman bagaimana sebaiknya mengelola limbah medis secara tepat. Kebijakan pada dasarnya merupakan garis sikap pemerintah ataupun pedoman untuk berbuat sesuatu. Jika dikaitkan dengan teori sebagaimana dikemukakan oleh Philipus M. Hadjon tentang kebijakan, pemerintah pusat telah menunjukkan sikapnya terkait dengan pengelolaan limbah medis dengan membuat suatu pedoman tertulis dalam bentuk peraturan kebijakan. Sejalan dengan teori kebijakan menurut H. Juniarso Ridwan dan Achmad Sodik Sudrajat, pemerintah pusat telah membuat peraturan kebijakan mengenai pengelolaan limbah medis melalui peraturan menteri. Pedoman pengelolaan limbah medis di fasyankes primer telah dikeluarkan dalam bentuk Permen LHK No. 56 Tahun 2015, Permenkes No. 27 tahun 2017, dan Permenkes No. 9 tahun 2009.

Pemerintah Kota Semarang pun telah mengambil sikap tegas bahwa semua kegiatan yang berpotensi memberi dampak kepada lingkungan harus diatur. Hal ini tercantum di dalam Perda Kota Semarang No. 13 Tahun 2006 Tentang Pengendalian Lingkungan Hidup. Namun, berdasarkan uraian yang telah penulis jabarkan, DLH Kota Semarang dan DKK Semarang masih terhambat oleh regulasi dalam menjalankan peran mereka kaitannya dengan pembinaan dan pengawasan pengelolaan limbah medis di fasyankes. Selain itu, ditemukan adanya kekosongan hukum dalam Perda tersebut kaitannya dengan izin lingkungan. Sebagaimana peraturan kebijakan yang diterbitkan oleh kedua menteri, Walikota Semarang pun dapat membuat instrumen hukum, baik dalam bentuk regulasi ataupun kebijakan yang mampu menengahi masalah ini.

Alternatif penyelesaian yang dilakukan oleh Pemkot Semarang dalam rangka mengatasi kekosongan hukum tersebut adalah dengan membuat kebijakan. Sebagaimana yang disampaikan oleh $\mathrm{H}$. Juniarso Ridwan dan Achmad Sodik Sudrajat mengenai konsep freies ermessen dalam negara hukum, bahwa pemerintah dapat mengambil kebijakan untuk menyelesaikan permasalahan yang belum diatur oleh peraturan perundang-undangan. Kebebasan ini tentu tetap harus dapat dipertanggungjawabkan yang artinya memiliki keterbatasan. Sebagaimana yang disampaikan oleh Prajudi Atmosudirjo dalam teorinya mengenai kebijakan, bahwa suatu kebijakan yang dikeluarkan pemerintah tidak boleh melanggar asas-asas hukum. Kebebasan yang dimiliki Pemkot Semarang sebagaimana dikemukakan oleh H. Juniarso dan Achmad Sodik Sudrajat dalam teorinya mengenai kebijakan, tetap harus berorientasi pada penyelesaian masalah untuk melayani publik serta tidak bertentangan dengan sistem hukum yang ada. Kebijakan yang dikeluarkan oleh Pemkot Semarang mengenai pengelolaan limbah medis di fasyankes primer harus 
tetap mempertimbangkan batasan kewenangan yang secara konkret dijabarkan dalam matriks pembagian urusan pemerintahan dalam lampiran UU No. 23 Tahun 2014, wewenang Walikota terkait pengendalian lingkungan hidup dalam Perda Kota Semarang No. 13 Tahun 2006, wewenang dalam hal perizinan dalam Perda Kota Semarang No. 8 Tahun 2014, tugas dan fungsi Dinas Lingkungan Hidup Kota Semarang dalam Perwal No. 72 Tahun 2016, tugas dan fungsi Dinas Kesehatan Kota Semarang dalam Perwal No. 62 Tahun 2016, serta standar pelayanan publik Dinas Lingkungan Hidup dalam Perwal No. 4 Tahun 2013 yang diubah menjadi Perwal No. 17 Tahun 2017.

Dalam mengatasi kekosongan hukum dalam perda tersebut, DPMPTSP bersama DKK Semarang telah mengeluarkan kebijakan untuk internal pemerintahan kaitannya dengan perizinan. Sebagaimana yang disampaikan oleh Jimly Ashidiqque dalam teorinya mengenai kebijakan, Pemkot Semarang dapat mengeluarkan kebijakan yang sifatnya prosedural- administratif untuk membimbing lembaga pelaksana melaksanakan tugas jabatannya. Kebijakan tersebut dikeluarkan dalam bentuk aturan kebijakan. Aturan kebijakan tersebut dikeluarkan dalam bentuk standar prosedur operasional perizinan klinik. Di dalam standar prosedur penerbitan izin klinik, disebutkan bahwa klinik rawat jalan wajib memiliki dokumen lingkungan setingkat SPPL. Sedangkan bagi klinik rawat inap wajib memiliki dokumen lingkungan setingkat UKL-UPL. Pelaksana layanan izin SPPL dan izin operasional klinik didelegasikan oleh Walikota kepada DPMPTSP sebagaimana di dalam Perwal No. 70 Tahun 2019. Namun, menurut penulis, aturan kebijakan ini masih menimbulkan masalah. Dokumen SPPL pada dasarnya hanya berupa surat pernyataan bermaterai yang menyatakan bahwa penanggungjawab usaha sanggup melakukan pengelolaan lingkungan hidup terutama dalam kaitannya dengan pengelolaan limbah hasil usahanya. Di dalam dokumen tersebut penanggungjawab kegiatan menjabarkan gambaran teknis kegiatan yang dijalankan, luas tanah dan bangunan, sarana kegiatan, limbah apa saja yang dihasilkan, dan kegiatan pengelolaan limbah yang sudah dihasilkan tadi. Limbah medis merupakan bagian dari limbah B3 yang mana pasti memiliki potensi menimbulkan dampak penting bagi lingkungan maupun kesehatan masyarakat. Oleh karena itu, menjadi kurang tepat jika klinik hanya mengurus izin lingkungan setingkat SPPL. Selain itu, melihat situasi saat ini, diskresi ini dianggap penulis tidak sesuai lagi. Apalagi melihat fenomena pandemi Covid-19 yang sedang melanda Indonesia. Kemudian, berdasarkan hasil wawancara dengan DLH Kota Semarang, usaha yang izin lingkungannya setingkat SPPL tidak wajib memiliki TPS limbah B3. Padahal amanah memiliki TPS limbah B3 telah disampaikan oleh regulasi diatasnya, yakni di PP No 101 Tahun 2014, Permen LHK No 56 Tahun 2015, dan Permenkes No. 27 tahun 2017. Selain itu, keberadaan TPS limbah B3 di fasyankes khususnya klinik menjadi penting kaitannya dengan masalah teknis pengangkutan limbah B3 oleh pihak ketiga.

Sebagaimana yang telah dinyatakan dalam Perda Kota Semarang No 13 Tahun 2006 bahwa penyimpanan sementara limbah B3 itu wajib memiliki izin. Penerbitan izin TPS limbah B3 merupakan domain dari DLH Kota Semarang. DLH Kota Semarang telah mengeluarkan aturan kebijakan dalam bentuk standar prosedur operasional pengajuan izin TPS limbah B3. Di dalam standar prosedur operasional tersebut, syarat administrasi yang harus terpenuhi penghasil limbah B3 salah satunya wajib memiliki dokumen lingkungan AMDAL, UKL-UPL, atau SPPL. Namun, pelaksanaan pengajuan izin TPS limbah B3 di lapangan belum dapat dilaksanakan oleh klinik. Seperti yang 
telah penulis sampaikan sebelumnya bahwa terdapat perbedaan acuan dan pembagian tugas dari kedua dinas ini. Hal ini mengakibatkan pengawasan dan pembinaan dinas daerah terkait pengelolaan limbah medis di fasyankes primer menjadi terhambat. Pelaksanaannya di fasyankes primer pun menjadi tidak sesuai dengan ketentuan perundang-undangan yang ada. DKK Semarang dalam peranannya sebagai pembina fasyankes primer belum secara tegas mewajibkan hal tersebut karena belum diatur di dalam Permenkes. Di dalam Permenkes No.27 Tahun 2017 memang disebutkan untuk fasyankes perlu memiliki TPS limbah B3. Namun syarat kelayakan dan kewajiban memiliki izin TPS limbah B3 ada di dalam Permen LHK No.56 Tahun 2015 yang mana ketentuan tersebut belum dilaksanakan oleh klinik.

Kebijakan pengelolaan limbah medis lain di kota Semarang yang penulis temukan adalah kewajiban bagi klinik untuk bekerja sama dengan pihak ketiga pengelola yang memiliki izin dari KLHK. Fasyankes primer seperti klinik dan drg mandiri tidak dapat mengelola limbah medisnya secara mandiri. Oleh karena itu mereka sebetulnya perlu bekerja sama dengan perusahan pengolah limbah B3. Kebijakan ini penulis temukan dalam bentuk aturan kebijakan berupa standar prosedur operasional pengajuan izin operasional klinik. Syarat administrasi yang wajib terpenuhi klinik untuk dapat mengajukan izin operasional adalah memiliki dokumen perjanjian kerja sama antara klinik dengan perusahaan pengelola yang berizin. Dengan demikian, pengelolaan limbah medis di klinik selanjutnya tidak dibuang ke lingkungan melainkan diolah lebih lanjut oleh pihak ketiga. Pihak ketiga yang penulis temukan di dokumen perjanjian kerja sama klinik yang menjadi narasumber penulis adalah PT Arah Environmental Indonesia.

Kebijakan Pemkot Semarang dalam pengelolaan limbah medis di tingkat dokter gigi praktik mandiri di Kota Semarang belum ada. Berdasarkan hasil wawancara penulis dengan Seksi Sumber Daya Kesehatan DKK Semarang, peran DKK Semarang hanya sebatas penerbitan izin praktik dokter gigi. Dokter gigi praktik mandiri tidak memiliki kewajiban untuk memiliki izin lingkungan sebagai syarat administrasi penerbitan izin praktik. DKK Semarang telah bekerja sama dengan PDGI cabang Semarang untuk memberikan rekomendasi. Dalam hal penerbitan rekomendasi, PDGI Cabang Semarang meninjau dokter gigi yang akan mengurus izin praktiknya. PDGI cabang Semarang mengeluarkan aturan kebijakan terkait pengelolaan limbah medis di dokter gigi praktik mandiri dalam bentuk standar prosedur operasinal penerbitan surat rekomendasi. Surat rekomendasi tersebut nantinya berfungsi sebagai syarat administratif pengurusan izin praktik dokter gigi. Di dalam SPO tersebut, poin pengelolaan limbah medis hanya sebatas pada ketersediaan tempat sampah berlabel infeksius yang dipisah dengan tempat sampah berlabel non infesksius di ruang praktik. Selain itu, kaitannya dengan limbah cair, dokter gigi praktik mandiri wajib memiliki septic tank. Menurut hasil wawancara dengan DLH Kota Semarang dan DKK Semarang, untuk dapat mewajibkan dokter gigi praktik mandiri bekerja sama dengan pihak ketiga pengelola limbah medis dan memiliki TPS limbah B3 dinilai memberatkan. Hal ini memberatkan karena volume limbah yang dihasilkan tidak sebanding dengan biaya yang harus dikeluarkan. Biaya untuk menyerahkan urusan pengolahan limbah medis kepada pihak ketiga dinilai mahal. Hal ini menjadi mempersulit pelaksanaan pengelolaan limbah medis sesuai dengan peraturan perundang-undangan. Menurut DLH Kota Semarang, biaya menjadi mahal karena biaya akses untuk pengambilan limbah di fasyankes dan biaya pengangkutan limbah 
ke pusat pengolahan yang terdapat di luar kota Semarang. Berdasarkan hasil wawancara penulis dengan DLH Kota Semarang, pengumpulan limbah medis setingkat dokter gigi praktik mandiri seharusnya bisa menjadi PAD Kota Semarang. Kegiatan ini bisa dikoordinasikan oleh Pemkot Semarang dalam hal ini bisa menjadi kebijakan yang diambil oleh Walikota.

\section{Pelaksanaan Pengelolaan Limbah Medis di Klinik Gigi dan Dokter Gigi Praktik Mandiri}

\section{a. Penemuan Limbah Medis Yang Dihasilkan Di Klinik Gigi Dan Dokter Gigi Praktik} Mandiri

Limbah medis sebagaimana yang dikemukakan oleh Rosihan dalam teroinya mengenai limbah medis merupakan hasil aktivitas pelayanan medis yang mana perlu dikelola secara khusus. Limbah medis padat yang sebagian besar dihasilkan di klinik gigi dan dokter gigi praktik mandiri yakni limbah infeksius, limbah benda tajam, dan limbah patologis. Limbah infeksius yang dihasilkan berupa

1) alat pelindung diri (APD) sekali pakai

2) cotton roll, cotton pellet, kassa, dan tampon yang terkontaminasi darah dan saliva pasien

3) bur yang sudah aus bekas pasien

4) potongan bahan restorasi pasien baik amalgam, resin komposit, maupun semen.

Limbah patologis yang dihasilkan yakni gigi bekas pencabutan, potongan jaringan gusi, fragmen tulang alveolar, serta fragmen karang gigi hasil scaling. Limbah benda tajam yang dihasilkan antara lain jarum suntik, scalpel blade yang sudah terpakai, pecahan ampul obat anestesi, dan jarum endodontik bekas pakai. Limbah cair yang dihasilkan di klinik gigi dan dokter gigi praktik mandiri adalah darah, saliva, air kumur pasien, cairan saliva hasil suction, dan air sisa aktivitas bur dan scaler. Klinik dan dokter gigi juga menghasilkan limbah farmasi tetapi sangat sedikit. Limbah farmasi yang dihasilkan berupa bahan sterilisasi saluran akar yang kadaluarsa seperti pasta devitalisasi pulpa, trikresolformalin, formokresol, eugenol, maupun ChKm (chlorfenol kamfer menthol), serta karpul atau ampul anestesi.

b. Tahap Pengelolaan Limbah Medis Yang Sudah Dilaksanakan Di Klinik Gigi Dan Dokter Gigi Praktik Mandiri

Pemerintah telah mengeluarkan pedoman mengenai limbah medis apa saja yang perlu dikelola dan bagaimana mengelolanya. Hal ini telah dijabarkan di dalam PP No. 101 Tahun 2014, Permen LHK No. 56 Tahun 2015, dan Permenkes No. 27 Tahun 2017.

\section{1) Pengurangan dan Pemilahan}

Seperti yang direkomendasikan oleh WHO, tahap ini merupakan tahap yang paling awal dan paling penting dalam rangkaian prosedur pengelolaan limah medis. Tahap pengurangan merupakan bentuk pengendalian terhadap sumber limb ah B3 yang mungkin akan dihasilkan. Sebagian besar klinik dan dokter gigi praktik mandiri yang penulis jadikan narasumber telah melaksanakan tahap pengurangan dalam bentuk:

a) mengganti tensimeter bermerkuri dengan yang tidak bermerkuri

b) menggunakan alat diagnostik, alat bedah, dan alat restorasi yang sifatnya reusable 
Peralatan medis reusable masih mendominasi. Hal ini menimbulkan konsekuensi pada prosedur desinfeksi alat yang klinik dan dokter gigi praktik mandiri lakukan yakni dengan cairan kimia. Terkait dengan pengendalian sumber limbah B3, klinik dan dokter gigi praktik mandiri yang menjadi narasumber penulis memang belum melakukan kontrol terhadap sumber bahan kimia dan farmasi yan digunakan seperti misalnya melakukan kontrol terhadap bahan-bahan yang kadaluarsa maupun kontrol stok bahan. Hal ini disebabkan karena keduanya belum memiliki prosedur standar dalam hal pengendalian bahan kimia dan farmasi yang digunakan.

Semua klinik dan dokter gigi praktik mandiri telah memisahkan limbah medis yang sifatnya infeksius dan non infeksius. Mereka mengerti limbah apa saja yang termasuk dalam kategori infeksius yang mana merupakan limbah yang berkontak dengan darah dan cairan tubuh pasien. Sebagaimana yang direkomendasikan oleh WHO bahwa pemilahan tersebut dilakukan dengan menempatkannya di tempat sampah berlabel terpisah di dalam ruang praktek. Pemilahan juga dilakukan terhadap limbah medis benda tajam. Sebagaimana yang disampaikan oleh Asmadi dalam teorinya mengenai pengelolaan limbah medis, benda tajam wajib dimasukkan ke dalam tempat yang tahan terhadap tusukan dan berwarna kuning sebagai tandanya. Semua limbah benda tajam yang dihasilkan telah ditempatkan di dalam safety box berwarna kuning.

\section{2) Penampungan Sementara}

Di dalam PP 101 Tahun 2014 dan Permen LHK No.56 tahun 2015 telah disebutkan bahwa semua penghasil limbah B3 wajib menampung sementara limbah B3 yang dihasilkannya. Hal ini berkaitan dengan masa simpan limbah medis hingga nantinya diangkut oleh pihak ketiga pengelola limbah medis. Menurut Asmadi, penyimpanan sementara limbah medis padat harusnya dilakukan paling lama 48 jam pada musim kemarau atau 24 jam pada musim hujan. Di dalam Pasal 8 ayat (2) poin a dan b Permen LHK No. 56 Tahun 2015 mengatur mengenai masa simpan limbah medis. Untuk kategori limbah padat infeksius dan patologis disimpan paling lama 2 hari pada temperatur $>0^{\circ} \mathrm{C}$ atau 90 hari pada temperatur sama atau $<0^{\circ} \mathrm{C}$. Sedangkan untuk limbah bahan kimia kadaluarsa dan limbah farmasi disimpan paling lama 180 hari jika yang dihasilkan kurang dari $50 \mathrm{~kg}$ perhari. Dengan demikian, keberadaan TPS limbah B3 sangat penting untuk menjamin limbah medis tersebut tetap tersimpan dengan aman.

Klinik dan dokter gigi praktik mandiri yang menjadi responden penulis belum memiliki TPS limbah B3 sesuai ketentuan. Limbah mereka hanya mereka simpan di tempat sampah berlabel infeksius di ruang praktek didiamkan hingga penuh kemudian dipindahkan ke tempat sampah yang lebih besar setiap seminggu sekali. Selanjutnya untuk klinik, limbah medis dibiarkan disana hingga waktu pengambilan pihak ketiga tiba. Pengambilan oleh pihak ketiga biasanya setiap 3 bulan sekali. Untuk yang di dokter gigi praktik mandiri, mereka belum bekerja sama dengan pihak ketiga. Jadi sebagian besar limbah medisnya dibuang bersama sampah rumah tangga. Limbah benda tajam yang dihasilkan umumnya dikumpulkan hingga safety box terssebut penuh. Untuk bisa menjadi penuh perlu waktu beberapa bulan hingga 1 tahun. Biasanya jika sudah penuh, safety box tersebut akan mereka titipkan ke kerabat atau teman yang bekerja di klinik atau hanya mereka simpan di 
ruang praktek. Menyimpan limbah medis di tempat praktek selama berbulan-bulan sebetulnya tidak benar dan pasti menimbulkan risiko. Penempatan limbah medis seperti ini di salah satu klinik telah menimbulkan keluhan bau tidak sedap di sekitarnya.

\section{3) Pengangkutan dan Pengolahan}

Tahap pengangkutan dilaksanakan oleh klinik. Tahap pengangkutan dilakukan pada saat pemindahan limbah medis dari tempat sampah di ruang praktek ke tempat sampah besar di luar ruangan. Bagi klinik yang memiliki banyak cabang, limbah medis dari berbagai cabang akan diangkut ke satu cabang klinik yang mana nanti pihak ketiga akan mengambilnya disana. Selanjutnya, pengangkutan limbah medis akan dilakukan oleh pihak ketiga untuk selanjutnya dibakar. Namun, perlakuan petugas terhadap limbah medis tersebut masih seperti memperlakukan sampah biasa. Pengangkutan dilakukan oleh petugas dengan tidak mengenakan APD. Untuk tingkat dokter gigi praktik mandiri, tahap pengangkutan tidak dilaksanakan.

Bagi klinik yang telah bekerja sama dengan pihak ketiga, tahap ini masih menimbulkan kendala. Pengangkutan limbah medis oleh pihak ketiga dilakukan setiap 3 bulan sekali. Sementara limbah medis tidak bisa disimpan begitu saja selama kurun waktu tersebut. DLH Kota Semarang dalam hal ini telah menganjurkan fasyankes untuk memiliki cold storage. Cold srorage dengan pengaturan suhu hingga $<0^{\circ} \mathrm{C}$ mampu memperpanjang masa simpan limbah medis hingga 3 bulan. Ini bisa mejadi solusi yang baik jika dilaksanakan oleh semua fasyankes primer. Namun, baik klinik maupun dokter gigi praktik mandiri belum mengetahui ini. Dinas Kesehatan Kota Semarang sendiri masih menghimbau Puskesmas untuk memiliki cold srorage ini.

Sesuai dengan amanah Permenkes 27 Tahun 2017, apabila fasyankes tidak mampu mengelola limbah medisnya secara mandiri, maka sebaiknya fasyankes tersebut wajib bekerja sama dengan pihak ketiga. Pihak ketiga tersebut wajb memiliki izin dari KLHK. Di dalam spo penerbitan izin operasional klinik di DPMPTSP, klinik wajib melakukan kerja sama dengan pihak ketiga untuk bisa mengajukan dan memperpanjang izin operasional kliniknya. Klinik yang menjadi responden penulis dinilai cukup disiplin dalam hal perpanjangan masa kontrak dengan pihak ketiga pengelola. Hal ini dinilai penulis berasal dari ketegasan DKK Semarang dalam memantau pelayanan di fasyankes khususnya di klinik. Untuk tingkat dokter gigi praktik mandiri, tidak ada kewajiban untuk bekerja sama dengan pihak pengolah. Pengolahan selanjutnya sepenuhnya diserahkan kepada kesadaran dokter gigi praktik mandiri tersebut. Karena tidak mempercayakan kepada pihak ketiga, limbah medis tersebut ada yang dibuang bersama sampah rumah tangga, ada yang dititipkan kerabatnya yang memiliki klinik, ada pula yang disimpan begitu saja.

\section{4) Pengelolaan limbah cair}

Limbah cair sebagaimana yang disebutkan dalam Perda Kota Semarang wajib dikelola dengan membangun IPAL. Di tingkat fasyankes primer, pembangunan IPAL ini tidak dilaksanakan. Dinas Kesehatan Kota Semarang melalui tim dari bidang SDK dan Yankes mewajibkan untuk klinik memiliki septic tank khusus. Untuk dokter gigi praktik mandiri, kewajiban memiliki septic tank khusus 
dinyatakan oleh PDGI Cabang Semarang. Namun pada kenyataannya, masih ada dokter gigi responden penulis yang masing membuangnya ke saluran domestik.

\section{Faktor Yang Mendukung Dan Menghambat Pelaksanaan Kebijakan Pemerintah Kota Semarang Dalam Pengelolaan Limbah Medis di Klinik Gigi dan Dokter Gigi Praktik Mandiri}

Pemerintah Kota Semarang telah berusaha menyelenggarakan tugas pemerintahan dalam bidang pengelolaan limbah medis di fasyankes. Beberapa langkah kebijakan pun telah dikeluarkan untuk tetap terselenggaranya pelayanan publik bagi warga masyarakat meskipun belum diatur lebih jelas di dalam perda. Dalam melaksanakan kewenangannya, pemerintah memiliki faktor- faktor yang bisa mendukung dan menghambat ketika menyelenggarakan pelayanannya.

\section{a. Faktor yuridis}

Penulis menemukan kekosongan hukum dalam hal penerbitan izin lingkungan di Kota Semarang. Walikota Semarang belum mengatur mengenai jenis usaha apa yang wajib SPPL maupun UKL-UPL. Hal ini berefek kepada pelaksanaan pengelolaan limbah medis di fasyankes.

Di klinik, diskresi pemerintah untuk klinik rawat jalan memiliki SPPL menjadi tidak relevan lagi. Dokter gigi praktik mandiri yang juga merupakan salah satu fasyankes penyelenggara pelayanan kesgilut belum diwajibkan memiliki izin lingkungan sebagai bukti bahwa mereka mengelola limbah medis yang dihasilkannya. Bagi klinik, DPMPTSP bersama DKK telah mengeluarkan kebijakan terkait perizinan dalam bentuk standar prosedur operasional penerbitan izin operasional klinik. Untuk bisa mengurusnya, klinik gigi sebagai bagian dari klinik rawat jalan wajib memiliki SPPL dan memiliki dokumen kerja sama dengan pihak ketiga pengelola limbah yang berizin. Namun, kebijakan ini masih menimbulkan masalah. Di dalam dokumen SPPL tidak ada ketentuan bagi penghasil untuk memiliki sarana TPS limbah B3. Amanah memiliki TPS limbah B3 sebetulnya ada di dalam PP. Dengan kebijakan tersebut, pengelolaan limbah medis di klinik gigi belum terlaksana sesuai ketentuan perundang- undangan yang ada.

Sebagaimana yang telah penulis uraian sebelumnya bahwa terdapat tumpang tindih regulasi di tingkat kementrian. Tumpang tindih regulasi pengelolaan limbah medis diantara Permen LHK dan Permenkes membuat pedoman pengelolaan limbah medis menjadi membingungkan. Perbedaan acuan tersebut menyebabkan peran kedua dinas dalam melakukan pembinaan dan pengawasan menjadi tidak maksimal. Menurut penulis, kendala dalam faktor yuridis ini perlu diselesaikan juga secara hukum. Walikota sebagai kepala daerah kota Semarang perlu membuat produk hukum yang bertujuan untuk menyelesaikan ini.

\section{b. Faktor sosiologis}

Di tingkat klinik, kesadaran akan bagaimana mengelola limbah medisnya lebih baik daripada di tingkat dokter gigi praktik mandiri. Namun, kesadaran ini lebih karena faktor paksaan dari aturan yang ada. Hal ini dipengaruhi oleh kebijakan DPMPTSP bersama DKK yang menyatakan bahwa untuk bisa memiliki izin operasional klinik wajib memiliki izin lingkungan setingkat SPPL. Selain izin lingkungan, klinik juga wajib memiliki dokumen kerja sama dengan pihak ketiga yang berizin untuk mengelola limbah medisnya. Bagi klinik yang bekerja sama dengan BPJS Kesehatan, setiap tahun 
ada kredensialing yang dilakukan oleh tim dari BPJS Kesehatan bersama dengan DKK Semarang. Kredensialing ini bertujuan untuk memeriksa kelayakan operasional dan ketertiban izin yang dimiliki oleh klinik. Izin operasional klinik wajib diperbaharui setiap 5 tahun sekali. Dalam prosesnya, pembaharuan izin klinik, berkas seperti dokumen lingkungan dan dokumen perjanjian kerja sama pengelolaan limbah medis dengan pihak ketiga wajib dimiliki sebagai syarat administratif. Sebagian besar klinik yang penulis wawancara masih belum mengetahui bagaimana mengelola limbah medis sesuai dengan ketentuan perundang-undangan.

Di tingkat dokter gigi praktik mandiri, pengelolaan limbah medis hanya sebatas pada pemisahan limbah medis dengan limbah rumah tangga di ruang praktik. Kesadaran untuk mengelola limbah medis sesuai peratutan yang ada belum dimiliki oleh sebagian besar dokter gigi yang ditemui penulis. Bahkan mereka tidak mengetahui secara jelas bagaimana cara yang benar. Hal ini juga dipengaruhi oleh masalah biaya kerja sama dengan pihak ketiga yang menurut mereka mahal. Namun, dalam pedoman yang dikeluarkan pemerintah sudah jelas bahwa limbah medis tidak dapat diperlakukan seperti sampah rumah tangga. Hal ini artinya limbah medis tidak dapat dibuang begitu saja di tempat sampah domestik. Sebagaimana yang telah dinyatakan oleh DLH Kota Semarang bahwa kendala biaya disebabkan karena biaya pengangkutan dan pengiriman ke tempat pengolahan limbah itu mahal. Menjadi mahal karena limbah medis tadi harus dikirim ke luar kota.

\section{c. Faktor teknis}

Pemerintah Kota Semarang belum meiliki pedoman yang jelas dalam pengelolaan limbah medis di fasyankes primer. Namun, bukan berarti tidak ada acuan yang legal dalam melaksanakannya. Pedoman mengelola limbah medis telah dikeluarkan pemerintah pusat melalui Permen LHK No. 56 Tahun 2015 tentang Tata Cara dan Persyaratan teknis Pengelolaan Limbah Bahan Berbahaya dan Beracun Dari Fasilitas Pelayana Kesehatan. Menurut Pasal 7, fasyankes wajib memiliki tempat penyimpanan sementara. Jika mengacu pada PP No. 47 Tahun 2016 Tentang Fasyankes, klinik dan dokter gigi praktik mandiri masuk dalam kategori fasyankes. Hal ini menunjukkan bahwa klinik dan dokter gigi praktik mandiri pun sebetulnya wajib memiliki TPS limbah B3. Keberadaan TPS limbah B3 berkaitan dengan masa simpan limbah B3 sebelum dilakukan pengangkutan. Karakter limbah infeksius dan patologis di dalam Permen LHK No. 56 Tahun 2015 wajib disimpan dengan alternatif sebagai berikut:

(1) Dua hari pada temperatur lebih besar dari OOC

(2) Sembilan puluh hari pada temperatur sama dengan atau lebih dari $0^{\circ} \mathrm{C}$

Selain itu, TPS limbah B3 itu sendiri juga harus memiliki izin karena harus tersedia dengan kriteria tertentu. Kriteria tersebut dibuat dalam rangka menjamin keamanan selama limbah medis tersebut masih tersimpan di fasyankes. Di kota Semarang, keberadaan TPS limbah B3 tidak menjadi kewajiban bagi klinik yang hanya memiliki dokumen lingkungan berupa SPPL. Oleh karena tidak diwajibkan, maka sebagian besar klinik tidak memilikinya. Menurut wawancara dengan DLH Kota Semarang, penyediaan tempat penyimpanan sementara limbah B3 bagi fasyankes kecil bisa difasilitasi oleh pemerintah kota. Namun, kembali lagi, kewenangan untuk mengeluarkan kebijakan ini ada di tangan Walikota. 
Pengangkutan oleh pihak ketiga dilakukan setiap 3 bulan sekali. Alasan yang diberikan oleh pihak ketiga yakni volume limbah medis yang dihasilkan sedikit jika diambil dalam kurun waktu 48 jam sesuai ketentuan peraturan perundang-undangan. Agar lebih efektif dan efisien, pengangkutan limbah medis di klinik diselenggarakan setiap 3 bulan. Melihat permasalahan ini, sangat disarankan fasyankes memiliki cold srorage yakni fasilitas pendingin yang memiliki temperatur sama atau lebih kecil dari ooC. Informasi ini belum banyak diketahui oleh fasyankes primer seperti klinik dan dokter gigi praktik mandiri. Menurut penulis, DKK Semarang sebagai dinas daerah yang mengerjakan urusan bidang kesehatan wajib mensosialisasikan, menghimbau, dan mewajibkan agar klinik dan dokter gigi praktik mandiri melakukan pengelolaan limbah medis yang benar, memiliki cold srorage yang tersimpan di dalam TPS limbah B3. Pertimbangannya adalah memastikan bahwa fasyankes melakukan pencegahan dan pengendalian infeksi di tempat kerja.

\section{KESIMPULAN}

Berdasarkan penelitian yang dilakukan oleh penulis mengenai kebijakan pengelolaan limbah medis di klinik gigi dan dokter gigi praktik mandiri dapat disimpulkan sebagai berikut:

\section{Kebijakan Pemerintah Kota Semarang Dalam Mengatur Pengelolaan Limbah Medis di} Klinik Gigi Dan Dokter Gigi Praktik Mandiri

Berdasarkan temuan data yang penulis temukan, jumlah klinik dan dokter gigi praktik mandiri di kota Semarang terus meningkat. Sebanyak 47\% klinik pratama memiliki pelayanan kesgilut satu atap. Sebanyak 31\% klinik utama di Semarang memberikan pelayanan kesgilut. Jumlah dokter gigi praktik mandiri pun mengalami peningkatan. Ketiga fasyankes primer ini jelas memberikan potensi produksi limbah medis yang besar di kota Semarang. Oleh karena itu, mengenai pengelolaan limbah medis di ketiga fasyankes ini seharusnya mulai mendapat perhatian perhatian serius dari Pemkot Semarang. Pemkot Semarang sebagai badan eksekutif bertanggung jawab mengatur, membina, dan mengawasi jalannya pengelolaan limbah medis karena limbah medis ini merupakan bagian dari limbah B3. Kebijakan internal Pemkot Semarang mengenai perizinan yang harapannya dapat mengatasi kendala pengelolaan limbah medis di ketiga fasyankes tersebut ternyata masih menimbulkan hambatan lain. Penulis menemukan kekosongan hukum dalam hal ketentuan jenis usaha apa saja yang wajib UKL-UPL ataupun SPPL di dalam Perda Kota Semarang. Untuk mengatasi kekosongan hukum tersebut, dinas daerah mengeluarkan kebijakan terkait perizinan. Secara tertulis, kebijakan ini dikeluarkan dalam bentuk standar prosedur operasional penerbitan izin operasional klinik. Dalam prosedur tersebut, klinik wajib memiliki dokumen lingkungan berupa SPPL dan dokumen kerja sama dengan pihak ketiga pengolah limbah. Kebijakan ini memberikan paksaan bagi klinik untuk disiplin dalam memperbaharui kontrak kerja sama dengan pihak pengolah. Namun kebijakan ini juga menghambat dalam pelaksanaan pengelolaan limbah medis karena tidak dapat mengatasi perbedaan acuan regulasi bagi DLH Kota dan DKK. Hal ini pun menghambat peran kedua dinas dalam membina dan mengawasi pengelolaan limbah medis yang mana sebetulnya juga bagian dari pengelolaan limbah B3. Hal ini membuat pelaksanaan pengelolaan limbah medis di klinik gigi juga tidak berjalan sesuai ketentuan yang ada.

Kekosongan hukum dalam Perda terkait perizinan membuat dokter gigi praktik mandiri sebagai penghasil tidak diwajibkan memiliki izin lingkungan. Hal ini berpengaruh dalam pelaksanaan pengelolaan limbah medis di dokter gigi praktik mandiri yang belum sesuai 
dengan ketentuan. Kebijakan Pemkot Semarang untuk dokter gigi praktik mandiri ditemukan dalam bentuk standar prosedur operasional penerbitan surat izin praktik. Di dalam prosedur tersebut, terkandung syarat administrasi berupa surat rekomendasi PDGI cabang Semarang. Penilaian kelayakan sarpras praktik mandiri khususnya dalam hal limbah medis diserahkan kepada PDGI cabang. Namun, kebijakan ini masih belum dapat membuat dokter gigi praktik mandiri mengelola limbah medis sesuai dengan regulasi yang ada. Hal ini disebabkan para dokter gigi belum tersosialisasi dengan baik mengenai cara mengelola limbah sesuai regulasi yang ada.

2. Pelaksanaan Pengelolaan Limbah Medis di Klinik Gigi dan Dokter Gigi Praktik Mandiri Secara umum, pengelolaan limbah medis di klinik dilaksanakan pada tahap pengurangan dan pemilahan, penampungan sementara, dan pengolahan limbah medis. Namun, proses pengelolaannya belum dilaksanakan sesuai dengan ketentuan yang sudah ada. Tahap pemilahan limbah medis sudah dilakukan dengan mengkategorikan dan menempatkan limbah medis tersebut secara terpisah. Namun, tahap penampungan sementara limbah medis ini belum dilakukan sesuai ketentuan yang ada. Di tingkat klinik, ada yang sudah memiliki TPS limbah medis, ada pula yang belum. Ketersediaan TPS limbah medis belum sesuai dengan ketentuan dan juga belum berizin.

Meskipun sudah diplastik terpisah, limbah medis dengan non medis masih bercampur di dalam TPS. Penempatan TPS pun belum terpisah dengan ruangan lain. Tahap pengolahan limbah medis diwujudkan dalam bentuk perjanjian kerja sama pengolahan limbah medis dengan pihak ketiga yang memiliki izin dari KLHK. Akibat adanya faktor paksaan dalam hal perizinan, klinik sudah berupaya disiplin dalam memperbaharui kontrak kerja samanya. Tahap pengangkutan masih menimbulkan kendala. Pihak ketiga pengolah mengambil limbah medis lebih dari waktu yang ditentukan dalam reguluasi. Tersedianya cold srorage menjadi alternatif penyelesaikan kendala ini karena mampu memperpanjang masa simpan limbah dan menjaga keamanan dari limbah tersebut hingga waktunya diambil. Namun, sarpras ini belum ada di klinik dan kebanyakan penanggungjawab klinik belum mengetahui hal ini.

Pengelolaan limbah medis di dokter gigi praktik mandiri baru dilaksanakan pada tahap pemilahan. Limbah yang banyak dihasilkan adalah limbah infeksius dan benda tajam. Di dalam ruang praktek, keduanya telah diletakkan di tempat terpisah. Namun, selanjutnya tahap penampungan sementara dan pengolahan belum dilakukan. Dokter gigi praktik mandiri belum memiliki TPS limbah medis. Limbah infeksius turut dibuang bersama sampah rumah tangga. Limbah benda tajam masih tersimpan di dalam ruang praktik. Dokter gigi praktik mandiri juga belum menjalin kerja sama dengan pihak pengolah berizin.

3. Faktor Yang Mendukung Dan Menghambat Pelaksanaan Kebijakan Pemerintah Kota Semarang Dalam Pengelolaan Limbah Medis di Klinik Gigi dan Dokter Gigi Praktik Mandiri

Dalam penelitian ini, penulis menjabarkan faktor-faktor yang mendukung dan menghambat dalam tiga kategori, yakni:

\section{a. Faktor Yuridis}

Faktor yang mendukung ditemukan penulis dalam bentuk regulasi berupa kewajiban pengelolaan limbah medis sebagai bagian dari limbah B3 yang tercantum Perda Kota Semarang No.13 Tahun 2006. Namun, faktor penghambat dari sisi yuridis ditemukan 
dalam hal adanya kekosongan hukum dalam hal perizinan lingkungan. Perda tersebut belum mengatur mengenai kegiatan usaha apa saja yang wajib memiliki SPPL atau UKL-UPL. Fasyankes klinik dan dokter gigi praktik mandiri merupakan penghasil limbah B3 yang mana perlu diatur dan diawasi oleh Pemkot Semarang. Kekosongan hukum ini membuat kedua fasyankes ini belum dapat mengelola limbah medisnya dengan benar.

Pemerintah pusat telah menerbitkan pedoman pengelolaan limbah medis di fasyankes melalui kedua peraturan menteri. Namun, pelaksanaannya masih menimbulkan kendala karena isinya saling tumpang tindih. Hal ini membingungkan pelaksanaan peran DLH Kota dan DKK Semarang karena masing-masing dinas memiliki acuan yang berbeda. Selain itu dalam praktiknya, perbedaan acuan ini membuat fungsi DKK dalam membina klinik dan dokter gigi praktik mandiri menjadi tidak optimal karena regulasi pengelolaan limbah medis dalam Permenkes masih terlalu longgar jika dibandingkan dengan yang ada di PP. Untuk mengatasi hambatan dalam sisi yuridis ini, Pemkot Semarang masih belum memiliki kebijakan tertulis yang berfungsi sebagai acuan produk hukum.

\section{b. Faktor Sosiologis}

Faktor yang mendukung menurut penulis ditemukan di dalam peran DPMPTSP dan DKK Semarang dalam pelayanan perizinan. Ada syarat administratif pengurusan izin operasional klinik berupa kepemilikan dokumen lingkungan dan dokumen perjanjian kerja sama dengan pihak ketiga yang berizin. Hal ini memaksa klinik untuk berusaha patuh untuk selalu memperbaharui kontrak kerjasama mereka dengan pihak ketiga. Faktor penghambat yang ditemukan penulis di tingkat klinik adalah kurangnya kesadaran dan kedisiplinan petugas dalam pelaksanaannya. Selain itu, pengetahuan mereka akan adanya pedoman pemerintah dalam mengelola limbah medis juga masih rendah. Di tingkat dokter gigi praktik mandiri, faktor penghambat lebih besar daripada faktor pendukung. Faktor pendukung ditemukan dalam bentuk pengawasan yang dilakukan oleh PDGI cabang Semarang dalam kaitannya dengan izin praktik. Faktor penghambat dijumpai dalam hal masih rendahnya kesadaran dan pengetahuan dokter gigi tentang bagaimana mengelola limbah medis sesuai ketentuan yang berlaku.

\section{c. Faktor Teknis}

Kendala teknis di tingkat klinik muncul di tahap penyimpanan sementara yang mana belum tersedia TPS limbah medis yang layak dan cold srorage. Selanjutnya kendala muncul pada tahap pengangkutan limbah medis. Pihak ketiga umumnya melakukan pengangkutan limbah medis di klinik setiap 3 bulan sekali. Padahal, di dalam peraturan perundang-undangan, pengambilan limbah medis idealnya dilakukan dalam waktu 2448 jam. Hal ini sebetulnya bisa diatasi dengan ketersediaan cold srorage di klinik. Namun, semua klinik yang penulis observasi belum memilikinya.

Di tingkat dokter gigi praktik mandiri, kendala teknis ini muncul pada tahap penampungan sementara dan pengangkutan. Tempat penyimpanan sementara limbah medis belum tersedia. Limbah medis yang sifatnya infeksius masih dibuang bersama sampah rumah tangga. Limbah benda tajam masih tersimpan di dalam ruang praktik. Kerja sama dengan pihak ketiga berizin tidak dilakukan karena biaya kerja sama yang dirasa terlalu mahal. 


\section{SARAN}

\section{Pemerintah Kota Semarang}

Walikota Semarang sebagai kepala daerah memiliki otoritas tertinggi dalam badan eksekutif kota Semarang. Walikota Semarang berwenang mengeluarkan produk regulasi maupun produk kebijakan yang mampu mengatasi hambatan di faktor yuridis ini. Walikota Semarang dapat merevisi Perda Kota Semarang No. 13 Tahun 2006 Tentang Pengendalian Lingkungan Hidup. Revisi ini berkaitan adanya kekosongan hukum mengenai usaha/kegiatan apa saja yang wajib memiliki dokumen lingkungan AMDAL, UKL-UPL, maupun SPPL. Selain itu, Walikota juga dapat mengeluarkan produk kebijakan baik berupa surat keputusan, surat edaran, maupun pedoman pelaksanaan pengelolaan limbah medis di klinik dan dokter gigi. Pedoman ini dapat menjadi acuan bagi dinas terkait dan klinik serta dokter gigi praktik mandiri dalam melaksanakan tugasnya masing- masing. Dalam penyusunannya, Pemkot Semarang dapat mengajak PDGI cabang Semarang dan Asosiasi Klinik untuk turut serta.

Penulis menemukan adanya pembagian tugas kedua dinas di lapangan yang justru menghambat peran pembinaan dan pengawasan terkait pengelolaan limbah medis di klinik dan dokter gigi praktik mandiri. Memang sebagai dinas daerah, DLH Kota dan DKK memiliki tugas dan fungsi masing-masing sesuai yang ada di Perwal. Namun, di lapangan, kedua dinas tersebut memerlukan koordinasi dalam membina dan mengawasi pengelolaan limbah medis di fasyankes. Perbedaan acuan pedoman pengelolaan limbah dapat diintegrasikan jika dalam prosesnya melibatkan satu sama lain. Koordinasi ini dilakukan dalam rangka mewujudkan amanah pengelolaan limbah medis yang tercantum dalam peraturan yang lebih tinggi dan juga demi tercapainya pelayanan kesgilut yang aman bagi fasyankes, masyarakat, maupun lingkungan sekitar.

Fungsi pembinaan pelayanan kesehatan di klinik dan dokter gigi praktik mandiri tidak hanya menjadi tugas DKK. Menurut Pasal 8 Permenkes No. 43 Tahun 2019 Tentang Puskesmas, puskesmas memiliki kewenangan untuk membina fasyankes primer di wilayah kerjanya. Melalui puskesmas, fasyankes dapat memperolah sosialisasi mengenai bagaimana sebaiknya mengelola limbah medis. Puskesmas dapat secara rutin meninjau kelengkapan sarpras khususnya dalam hal pengelolaan limbah medis yang ada di fasyankes primer lain di wilayah kerjanya. Hasil tinjauan tersebut dapat menjadi bahan binaan bagi fasyankes yang belum melaksanakan pengelolaan limbah sesuai regulasi yang ada.

Sejalan dengan hasil kebijakan yang disusun oleh KLHK dan Kemenkes, pengelolaan limbah B3 berbasis kewilayahan dapat menjadi salah satu alternatif untuk menekan biaya pengelolaan limbah medis yang dinilai mahal. Walikota Semarang sebetulnya dapat membuat TPS limbah B3 bagi penghasil limbah yang menghasilkan limbah B3 dalam volume yang kecil. Sarana ini dapat menjadi sumber PAD bagi kota Semarang yang mana selanjutnya dapat dimanfaatkan untuk mengembangkan fasilitas pengelolaan limbah B3 di kota Semarang menjadi lebih baik.

\section{Klinik}

Klinik diharapkan memenuhi sarana pengelolaan limbah medis sesuai ketentuan yang ada, yakni memiliki TPS limbah medis dan cold srorage. Dengan adanya kedua sarana ini, limbah medis dapat tersimpan denga aman hingga nantinya diangkut oleh pihak ketiga. Klinik juga diharapkan memiliki SPO pengelolaan limbah medis dan memonitoring 
pelaksanaannya sehingga pengelolaan limbah medis yang dilakukan oleh petugas dapat berjalan dengan baik.

\section{Dokter Gigi Praktik Mandiri}

Dokter gigi praktik mandiri sebaiknya membuat SPO pengelolaan limbah medis sesuai pedoman yang diterbitkan pemerintah. Adanya SPO ini memastikan dokter gigi praktik mandiri untuk melakukan pengelolaan limbah medis dengan benar. Selain itu, dokter gigi praktik mandiri sebaiknya menyampaikan kendala kerja sama dengan pihak ketiga kepada pengurus PDGl cabang Semarang. Harapannya, pengurus PDGI cabang Semarang dapat menjalin kolaborasi dengan dinas terkait dalam menentukan kebijakan untuk mencari solusi terbaik bagi dokter gigi yang berpraktik mandiri.

\section{PDGI Cabang Semarang}

PDGI cabang Semarang merupakan organisasi profesi yang mewadahi sejawat dokter gigi, baik itu general practitioner maupun spesialis. Organisasi profesi ini yang justru mengetahui apa saja kekurangan dalam pelayanan kesgilut di kota Semarang yang belum dapat terlaksana dengan baik. Salah satunya adalah mengenai limbah medis. Apalagi di masa pandemi ini, penanganan limbah medis menjadi penting agar tidak menjadi sumber penularan di tempat praktik. Kurangnya pengetahuan teman-teman sejawat dokter gigi sebetulnya dapat difasilitasi dengan mengadakan sosialisasi mengenai isi pedoman pelaksanaan pengelolaan limbah medis di fasyankes yang ada di peraturan menteri. Momen sosialisasi ini juga dapat menjadi wadah bagi dokter gigi praktik mandiri menyampaikan kendalanya terkait dengan pengelolaan limbah medis di tempat praktik. Aspirasi sejawat diharapkan dapat tertampung dengan baik dan selanjutnya dapat diajukan ke DKK selaku Pembina dari unsur pemerintahan.

\section{DAFTAR PUSTAKA}

Dewa Ayu Putu Gek Mega Suryasih Putri, dkk., "Manajemen Pengelolaan Limbah Medis Praktik Dokter Gigi Kabupaten Tabanan”, 2018, Bali Dental Journal, Vol.2, No.1, hlm 916.

Dinas Kesehatan Kota Semarang. "Profil Kesehatan Kota Semarang 2019", diakses dari https://dinkes.semarangkota.go.id/asset/upload/Profil/Profil/Profil\%20Kesehatan\%202 019.pdf, 20 Juli 2020.

Eko Nurmandiansyah, "Eco-Philosophy dan Implikasinya Dalam Politik Hukum Lingkungan Di Indonesia”, 2014, Melintas, Vol. 30(1), hlm 70-104.

Eko Susanto, Dinkes Semarang Bentuk Tim Terkait Temuan Sampah Medis, diakses tanggal 10 Mei 2019, Ambarawa, https://news.detik.com/berita-jawa-tengah/d3812602/dinkes-semarang- bentuk-tim-terkait-temuan-sampah-medis, detikNews.com.

M. Caniato, et al., "International Governance Structures for Health-Care Waste Management: A Systematic Review of Scientific Literature", 2015, Journal of Environmental Management, Vol. 153, hlm 93-107.

Michael Hangga Wismabrata, 4 Fakta di Balik Tumpukan Kantong Plastik Limbah Medis di Karawang, diakses tanggal 25 April 2019, https://regional.kompas.com/read/2018/09/10/06024971/4-fakta- di-balik-tumpukankantong-plastik-limbah-medis-di-karawang, Kompas.com. 
Muhamad Syahri Romdhon, Limbah Medis Berserakan di Tempat Pembuangan Sampah di Cirebon, diakses tanggal 25 April 2019, https://regional.kompas.com/read/2017/12/06/22291671/limbah- medis-berserakan-ditempat-pembuangan-sampah-di-cirebon, Kompas.com.

Rosihan Adhani, 2018, Pengelolaan Limbah Medis Pelayanan Kesehatan, Banjarmasin: Penerbit Pusaka Banua.

Rurie Marita Suryadewi, “Analisis Manajemen Pengelolaan Limbah Pelayanan Kesehatan Gigi (Studi Kasus pada Klinik The Aesthetic Dental \& Skin Clinic, RS. Tri Dipa, Puskesmas Pancoran, dan Puskesmas Pejaten Barat)", Tesis: Program Studi Ilmu Kesehatan Masyarakat, Program Pascasarjana Fakultas Kesehatan, Yogyakarta, 2016, hlm 37-55.

\section{Peraturan perundang-undangan}

Undang-Undang Dasar 1945

Undang-Undang No. 32 Tahun 2009 Tentang Perlindungan dan Pengelolaan Lingkungan Hidup

Undang-Undang No. 36 Tahun 2009 Tentang Kesehatan

Undang-Undang No. 23 Tahun 2014 Tentang Pemerintahan Daerah

Peraturan Pemerintah No.101 Tahun 2014 Tentang Pengelolaan Limbah Bahan Berbahaya dan Beracun

Peraturan Pemerintah No. 47 Tahun 2016 Tentang Fasilitas Pelayanan Kesehatan

Peraturan Pemerintah No 24 Tahun 2018 tentang Pelayanan Perizinan Berusaha Terintegrasi Elektronik

Peraturan Daerah Kota Semarang No. 13 Tahun 2006 Tentang Lingkungan Hidup

Peraturan Daerah Kota Semarang No. 5 Tahun 2008 Tentang Urusan Pemerintahan Yang Menjadi Kewenangan Pemerintah Daerah Kota Semarang

Peraturan Daerah Kota Semarang No. 8 Tahun 2014 Tentang Perizinan dan Non Perizinan

Peraturan Daerah Kota Semarang No. 14 Tahun 2016 Tentang Pembentukan dan Susunan Perangkat Daerah Kota Semarang

Peraturan Menteri Kesehatan No.9 Tahun 2009 Tentang Klinik

Peraturan Menteri Kesehatan No 46 Tahun 2015 Tentang Akreditasi Puskesmas, Klinik, Pratama, tempat Praktik Mandiri Dokter, dan Tempat Praktik Mandiri Dokter Gigi sebagaimana diubah denganPeraturan Menteri kesehatan No. 27 Tahun 2019 Tentang Perubahan Kedua Atas Peraturan Menteri Kesehatan Nomor 46 Tahun 2015 Tentang Akreditasi Puskesmas, Klinik Pratama, Tempat Praktik Mandiri Dokter, dan Tempat Praktik Mandiri Dokter Gigi

Peraturan Menteri Kesehatan No. 27 Tahun 2017 Tentang Pedoman Pencegahan Pengendalian Infeksi 
Peraturan Menteri Lingkungan Hidup dan Kehutanan No. 13 Tahun 2010 tentang Upaya Pengelolaan Lingkungan Hidup dan Upaya pemantauan Lingkungan Hidup dan Surat Pernyataan Kesanggupan Pengelolaan dan Pemantauan Lingkungan Hidup

Peraturan Menteri Lingkungan Hidup dan Kehutanan No. P.56/MENLHK-SETJEN/2015 Tentang Tata Cara dan Persyaratan Teknis Pengelolaan Limbah Bahan Berbaaya dan Beracun Dari Fasilitas Pelayanan Kesehatan

Peraturan Walikota Semarang No. 4 Tahun 2013 Tentang Standar Pelayanan Publik Badan Lingkungan Hidup Kota Semarang sebagaimana diubah dengan Peraturan Walikota Semarang No. 17 Tahun 2017 Tentang Perubahan Atas Peraturan Walikota Semarang Nomor 4 tahun 2013 Tentang Standar Pelayanan Publik Badan Lingkungan Hidup Kota Semarang.

Peraturan Walikota Semarang No. 62 Tahun 2016 Tentang Kedudukan, Susunan Organisasi, Tugas dan Fungsi, Serta Tata Kerja Dinas Kesehatan Kota Semarang

Peraturan Walikota Semarang No. 72 Tahun 2016 Tentang Kedudukan, Susunan Organisasi, Tugas dan Fungsi, Serta Tata Kerja Dinas Lingkungan Hidup Kota Semarang

Perwal No. 70 Tahun 2019 Tentang Pendelegasian Wewenang Penandatanganan Perizinan dan Non Perizinan Kepada Kepala Dinas Penanaman Modal dan Pelayanan Terpadu Satu Pintu Kota Semarang 